Acta vet. scand. $1964,5,279-286$.

Department of Bacteriology and Epizootiology \& Department of Animal Nutrition, Genetics and Hygiene, Royal Veterinary College, Stockholm, Sweden.

\title{
THE INTESTINAL FLORA IN PIGS WITH PARAKERATOSIS
}

I. THE INTESTINAL FLORA WITH SPECIAL REFERENCE TO ATYPICAL CLOSTRIDIUM PERFRINGENS AND CLINICAL OBSERVATIONS

By

Ingmar Månsson

Pigs self-fed a ration containing 15 to 20 per cent fishmeal acquire a great increase in the clostridial component of the intestinal flora (Mansson \& Olsson, $1961 \mathrm{a}, \mathrm{b}, \mathrm{c}$ ). Much of this increase can be referred to an organism which resembles Clostridium perfringens in many respects but differs for example through its pronounced proteolytic activity. This organism has been designated atypical Clostridium perfringens (Månsson $\&$ Smith, 1962). In conjunction with the change in the composition of the intestinal flora the pigs develop parakeratosis. The addition of 50 to $100 \mathrm{ppm}$ zinc to the feed leads to healing of the skin changes and if given prophylactically prevents their occurrence. Zinc supplementation, however, does not influence the composition of the intestinal flora, particularly the atypical Clostridium perfringens component. If one per cent citric acid is added to the feed, the number of atypical Clostridium perfringens will be greatly reduced and signs of parakeratosis do not appear or do so to only a slight degree (Månsson \& Olsson, 1962).

This paper is one of a series dealing with the effect of feeding on the composition of the intestinal flora and parakeratosis in pigs. Here, the clinical state of the animals is considered in relation to the intestinal flora. Blood and urine studies on the same pigs are described in subsequent papers. 


\section{MATERIAL AND METHODS}

Three groups (I-III) of Swedish lantras pigs had free access to dry feed from a self-feeder and to drinking water. No bedding was used in the boxes. The ration was based on cereals (oats and barley) and fishmeal. The composition of the basal diet is listed in table 1. The condition of the pigs was checked daily. Feed consumption and weight gains were recorded weekly at the same time as the faecal samples were taken for bacteriological examination.

Table 1.

Feed composition of "Basal diet«.

\begin{tabular}{lrrrrrr}
\hline Constituents & Kg & $\begin{array}{c}\text { Dry } \\
\text { matter }\end{array}$ & F.U.*) & $\begin{array}{c}\text { Digestible } \\
\text { protein; }\end{array}$ & Ca & P \\
\hline Barley & 36.5 & 31.8 & 37.6 & 2518 & 18 & 124 \\
Oats & 36.5 & 31.8 & 31.8 & 3212 & 32 & 127 \\
Wheat bran & 5.0 & 4.4 & 3.8 & 470 & 9 & 56 \\
Fish meal & 20.0 & 18.0 & 27.0 & 10790 & 1540 & 840 \\
Vitamin supplements & 1.0 & 0.9 & 0.2 & 70 & 230 & 20 \\
Limestone & 1.0 & 1.0 & - & - & 380 & - \\
\hline Total & 100.0 & 87.9 & 100.4 & 17060 & 2209 & 1167 \\
Digestible protein g/F.U. & & 170 & & & & \\
F.U./100 kg dry matter & & 114 & & & & \\
Ca/kg feed & & 22.1 & & & & \\
P/kg feed & 11.7 & & & & \\
Ca/P & 1.9 & & & & \\
\hline
\end{tabular}

*) Scandinavian feed units with an initial value of approximately $1 \mathrm{~kg}$ normal barley for feeding.

Group I consisted of six pigs - 292, 293, 299, 300, 302 and 303 - which weighed between 18 and $23 \mathrm{~kg}$ at the beginning of the experiment. They were fed the basal diet given in table 1 . Icelandic codmeal represented the fishmeal.

Group II consisted of six pigs $-1,2,4,6,7$ and 8 - which weighed between 17 and $22 \mathrm{~kg}$ at the beginning of the experiment. They were fed the basal diet; three of them (1, 2 and 4) also received $75 \mathrm{ppm}$ zinc as zinc sulphate.

Group III consisted of six pigs $-42,50,51,52,53$ and $55-$ which weighed between 16 and $20 \mathrm{~kg}$ initially. They were fed the basal diet with the Icelandic fishmeal replaced by Peruvian sardine meal. The Peruvian meal contained 2 per cent more raw protein and one per cent more fat. 


\section{Bacteriological examination}

Bacteriological examination of the intestinal content was carried out in the manner described previously (Månsson \& Olsson, $1961 \mathrm{a}, \mathrm{b})$.

\section{RESULTS}

Bacteriological examination of the intestinal flora

The examination comprised a quantitative determination of the number of coliforms, enterococci and clostridia. The $\mathrm{pH}$ of the faeces was also determined. Expressed in logs, the coliform counts were about 6 , the enterococci counts about 8 , and the $\mathrm{pH}$ values about 7 . No major changes in these values were noted during the course of the experiment, regardless of whether or not the animals developed parakeratosis. The clostridial component, on the other hand, has varied both quantitatively and to a less extent qualitatively. The groups responded differently in this respect.

Group I. During the first week of the experiment the faeces contained no clostridia or at the most some 150 per g faeces. By the second week the count began to rise and at the end of the third week was about $10^{5}$ per $g$ faeces. Throughout the rest of the experiment the count varied from $10^{5}$ to $10^{7}$ per $g$ faeces. During the second week the anaerobic flora consisted of atypical Clostridium perfringens and several anaerobic spore-formers; this flora can be considered non-specific. During the third week the atypical Clostridium perfringens increased and the other types decreased. Later on, the atypical Clostridium perfringens dominated the clostridial component.

Group II. Regardless of whether or not the animals received supplementary zinc, the coliform, enterococci and atypical Clostridium perfringens counts and the $\mathrm{pH}$ values were quite similar and followed the same pattern as in group I. As in group I, the clostridial count increased greatly and steadily during the first weeks. The high counts attained $\left(10^{5}-10^{7}\right.$ per g) persisted throughout the experiment. The composition of the clostridial component corresponded to that in Group I.

Group III. For this group, fed Peruvian sardine meal, the coliform and enterococci counts as well as $\mathrm{pH}$ values corresponded to those obtained for groups I and II. In group III, however, there was no obvious increase in clostridial counts during the eight weeks of the experiment. The faecal samples contained at the 
most 150 organisms per $g$ and were often negative. During the second and third weeks there was a slight increase in several of the anaerobic spore-forming types mentioned for group I. Later on, the number of these organisms was reduced and they were only sporadically represented during the rest of the experimental period.

\section{Clinical observations}

Group I. All animals developed signs of parakeratosis although the degree varied. On days 8 and 9 , a diffuse erythema appeared abruptly on the hindquarters, abdomen and the base of the ears of pigs 293 and 302 . They were killed on day 9 . At this time pigs 292, 299 and 300 were less severely affected and pig 303 had only very slight signs. By day 20, the skin changes on pigs 292, 299 and 300 had developed into typical parakeratosis. On the same day, erythema appeared suddenly over the hindquarters and abdomen of pig 303.

Appetite was fairly good during the first two weeks and the pigs gained between 2 and $3 \mathrm{~kg}$ each per week. During the third week appetite decreased and the pigs gained only one kg apart from pig 299 which did not gain at all.

The pigs were treated in various ways between days 20 and 27. Pigs 292 and 303 were injected intravenously every second day with $2.5 \mathrm{ml} 10$ per cent zinc chloride solution. The injections were given very slowly to avoid that the animals reacted with emesis and convulsions. Pigs $299(23.5 \mathrm{~kg})$ and $300(20.0 \mathrm{~kg})$ were given orally 250.000 IU penicillin daily for four days and then 500.000 IU for the next three days. This treatment was without apparent clinical effect and also the effect on the intestinal flora (only faeces samples investigated) was doubtful. The results of the zinc treatment were also doubtful. The appetite of pig 292 increased and the skin changes regressed to some extent. When treated, pig 303 was in the initial erythema stage; the appetite and skin changes did not improve during treatment. From day 27 onwards, the pigs were given $50 \mathrm{ppm}$ zinc as a dietary supplement. The skin changes regressed rapidly and the pigs quickly gained weight.

Group II. On days 24 and 25 pigs 6, 7 and 9 developed slight erythema on the lateral surfaces of the hindquarters and at the base of the ears. The animals, particularly pig 6 , were not nearly as severely affected as the pigs in group I. The skin changes 
progressed to typical parakeratosis without being preceded by an intensive initial stage with erythema involving much of the body surface. On day 42 the skin changes on pigs 7 and 9 were observed to be regressing. The clinical appearance accorded well with that described for pigs which first develop clinical signs at a weight of 30 to $35 \mathrm{~kg}$ (Månsson \& Olsson, $1961 \mathrm{a}, \mathrm{b}$ ). At the onset of clinical signs the pigs weighed 29,35 and $36 \mathrm{~kg}$. Their good appetite gave a daily weight gain of about $0.5 \mathrm{~kg}$ per day, evidence of the mildness of the clinical course. From day 35 onwards, $50 \mathrm{ppm}$ zinc was added to the feed and the skin changes regressed rapidly. Pigs 1, 2 and 4 in this group remained free from clinical signs throughout the entire experimental period, maintained a good appetite, and gained weight normally.

Group III. All pigs in this group remained free from clinical signs, had good appetite, and gained weight normally.

\section{DISCUSSION}

The purpose of this study was to follow the composition of the intestinal flora in pigs fed a dry, high-protein diet in a self feeder and with free access to water and at the same time to observe the development of parakeratosis. The feed for the three groups was based upon oats and barley with 20 per cent fishmeal. Groups I and II received Icelandic codmeal and group III Peruvian sardine meal. Half the pigs in group II were given a zinc supplement.

The composition of the intestinal flora in the pigs of groups I and II was influenced by the diet with a great increase in the clostridial counts. The quantitative and qualitative changes in the flora and the time at which these changes appeared confirmed previous observations using the same bacteriological techniques. The addition of zinc to the ration, as was the case in previous experiments (Månsson \& Olsson, $1961 \mathrm{a}, \mathrm{b}, \mathrm{c}$ ), did not affect the composition of the flora in this respect (pigs 1, 2 and 4 in group II). There was no corresponding change in the anaerobic flora of the pigs in group III. For as an yet unknown reason, there was no increase in the number of atypical Clostridium perfringens in this group.

Concomitant with the change in the anaerobic flora, skin changes which ultimately developed into typical parakeratosis appeared on the pigs in group I and those in group II (pigs 6, 7 
and 9) which did not receive supplementary zinc. The smaller the animal at the time of onset, the more severe were the skin changes. In such instances the onset was more abrupt and appeared as a diffuse erythema. The pigs in group II which received supplementary zinc (pigs 1, 2 and 4) remained free from clinical signs. Nor did the pigs in group III in which no change in the composition of the intestinal flora could be detected appear skin changes.

Intravenous treatment of a few affected animals with zinc did not give unequivocal results. Lewis et al. (1956), however, report good results with the injection of zinc in the form of zinc sulphate. Penicillin treatment was ineffective. No changes were noted in the intestinal flora. The general condition of the animals was poor and the appetite was greatly reduced. Prophylactic treatment with a suitable antibiotic could be tried to evaluate a possible effect upon parakeratosis. The addition of one per cent citric acid had a fairly good prophylactic effect and also greatly reduced the anaerobic flora (Månsson \& Olsson, 1962). Treatment intended to reduce the anaerobic component in the intestinal flora may prove successful. The results for group III point out the possibilities in this respect. As in previous experiments, the addition of zinc to the feed had a fully satisfactory therapeutic effect on parakeratosis.

The major differences in the results for the three groups can be summed up:

\begin{tabular}{llcc}
\hline & Feed & $\begin{array}{c}\text { Presence of atypical } \\
\text { Clostridium perfringens }\end{array}$ & $\begin{array}{c}\text { Signs of } \\
\text { parakeratosis }\end{array}$ \\
\hline Group I & basal & + & + \\
\hline Group II & basal & + & + \\
\cline { 2 - 4 } & $\begin{array}{l}\text { basal + } \\
75 \text { ppm zinc }\end{array}$ & + & - \\
\hline Group III & $\begin{array}{l}\text { basal with } \\
\text { Peruvian sardine } \\
\text { meal instead of } \\
\text { Icelandic codmeal }\end{array}$ & - & - \\
\hline
\end{tabular}

Other aspects of this experiment will be dealt with in subsequent papers. 


\section{REFERENCES}

Lewis, Jr., P. K., Hoekstra, W. G., Grummer, R. H. \& Phillips, P. H.: The effect of certain nutritional factors including calcium, phosphorus and zinc on parakeratosis in swine. J. Animal Sci. 1956, 15, 741-751.

Månsson, I. \& Olsson, B.: The intestinal flora of pigs. I. Quantitative studies of coliforms, enterococci, and clostridia in the faeces of pigs fed a high-protein and high-calcium diet. Acta Agric. Scand. 1961 a, 11, 197-210.

Idem. II. Further quantitative studies of coliforms, enterococci, and clostridia in the faeces of pigs self-fed a high-protein and highcalcium diet. Acta Agric. Scand. 1961 b, 11, 257-264.

Idem. III. The effect of dietary zinc on the number of coliforms, enterococci, and clostridia in the faeces of pigs self-fed a high-protein and high-calcium diet. Acta Agric. Scand. 1961 c, 11, 265-269.

Idem. IV. The effect of dietary citric acid on the number of coliforms, enterococci and clostridia in the faeces of pigs self-fed a highprotein and high-calcium diet. Acta Agric. Scand. 1962, 12, 3-8.

Månsson, I. \& Smith, L. DS.: Atypical strains of Clostridium perfringens from swine. Acta path. et microbiol. Scand. 1962, 55, 342-348.

\section{SUMMARY}

Two groups of pigs, groups I and II, were self-fed a basal diet. The composition of the diet is listed in Table 1. Another group, group III, was fed the same diet with the fish meal (Icelandic codmeal) replaced by Peruvian sardine meal. The composition of the intestinal flora in the pigs of group I and II was influenced by the diet with a great increase in the clostridial counts.

Concomitant with the change in the anaerobic flora, skin changes which ultimately developed into typical parakeratosis, appeared on those pigs which did not receive supplementary zinc. In group III no change of the intestinal flora could be detected and no skin changes appeared in this group.

\section{ZUSAMMENFASSUNG}

Die Darmflora bei Schweinen mit Parakeratose.

I. Die Zusammensetzung der Darmflora mit Rücksicht auf das Vorkommen von atypischen Clostridium perfringens und klinische Beobachtungen.

Zwei Gruppen von Schweinen, die Gruppen I und II, erhielten eine basal Diet welche Zusammensetzung aus der Tabelle I hervorgeht. Eine andere Gruppe Schweine, Gruppe III, erhielt dieselbe Diet aber mit dem Unterschied, dass das Fischmehl gegen peruanisches Sardinenmehl ausgetauscht war. In den Gruppen I und II wurde eine wesentliche Steigerung der Anzahl von atypischen Clostridium perfringens im Darm erhalten und gleichzeitig damit zeigten die Tiere Parakeratosesymptome, wenn sie nicht einen extra Zuschuss von Zink erhielten. 
In der Gruppe III wurde keine Steigerung der Anzahl atypischer Clostridium perfringens im Darm erhalten und diese Tiere verblieben symptomfrei.

\section{SAMMANFATTNING}

Tarmfloran hos grisar med parakeratos.

I. Tarmflorans sammansättning med särskild hänsyn till förekomsten av atypiska Clostridium perfringens och kliniska iakttagelser.

Två grupper av grisar, grupperna I och II, erhöllo en basal diet vars sammansättning framgår av Tabell 1. En annan grupp grisar, Grupp III, erhöll samma diet men med den skillnaden, att fiskmjölet utbytts mot peruanskt sardinmjöl. I gruperna I och II erhölls en väsentlig ökning av antalet atypiska Clostridium perfringens i tarmen och samtidigt härmed företedde djuren symptom på parakeratos, såvida de ej erhöllo extra tillskott på zink. I grupp III erhölls ingen ökning av antalet atypiska Clostridium perfringens i tarmen och dess djur förblevo symptomfria.

(Received December 31. 1963). 